Caligrama, Belo Horizonte, v. 23, n. 2, p. 121-143, 2018

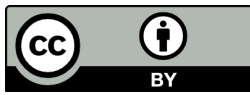

\title{
Arabismos portugueses no contexto multilinguístico da Península Ibérica Medieval
}

\section{Portuguese arabisms in the Medieval Iberia's multilinguist context}

\author{
Samantha de Moura Maranhão \\ Universidade Federal do Piauí, Teresina, Piauí / Brasil \\ samantha.ufpi@gmail.com
}

Resumo: Este estudo tem por objeto a aquisição de arabismos pelos falares regionais, e particularmente pela língua portuguesa, no contato multilinguístico verificado na Península Ibérica, durante a Idade Média. Apresenta a história externa da língua portuguesa, com a definição e a caracterização dos espaços que a geopolítica então delimitou e as relações estabelecidas entre diferentes grupos étnico-religiosos, cristão, muçulmano e judeu, que os compartilharam. O problema da pesquisa é: "O que informa a literatura especializada acerca do contato de línguas na Ibéria Medieval?” A hipótese testada é a de que a diglossia árabe-romance está fartamente documentada na literatura especializada no tema dos arabismos ibéricos medievais. Fundamentam este estudo obras sobre arabismos (VARGENS, 2007; CORRIENTE, 1996), história da língua portuguesa (TEYSSIER, 2001; VASCONCELOS, 1956; SILVANETO, 1988) e história (CONSTABLE, 1997; THORAVAL, 1996).

Palavras-chave: linguística de contato; arabismos ibéricos; língua portuguesa.

Abstract: This study examines the diffusion and integration of the Arabic Language into other languages, particularly Portuguese, in the context of multilingualism in the Iberian Peninsula in the Middle Ages. The paper begins by briefly presenting the history and definition of the Portuguese language, followed by an examination of geopolitical spaces and the relationships among the different ethnic and religious groups--including Christians, Muslims and Jews--that shared them. The research question, "What does literature say about language contact in the Medieval Iberia?" will be assessed in this paper. In addition, we tested the hypothesis that the Arab-Romance diglossy is heavily 
documented in the literature specialized in Medieval Iberian Arabisms. This study is based on authors specialized in Arabisms (VARGENS, 2007; CORRIENTE, 1996), on the history of the Portuguese language (TEYSSIER, 2001; VASCONCELOS, 1956; SILVA NETO, 1988) and on History (CONSTABLE, 1997; THORAVAL, 1996).

Keywords: contact linguistics; Iberian arabisms; Portuguese language.

\section{Introdução}

Este estudo tem por objeto o contato multilinguístico na Península Ibérica, durante a Idade Média, uma vez que o tema das marcas arábicoislâmicas na língua portuguesa, abordado na perspectiva da sócio-história da língua, demanda a contextualização do ambiente cultural em que se deu o contato entre falares ibéricos e a língua corânica. Apresentamos, assim, a história externa da língua portuguesa, com a definição e a caracterização dos espaços que a geopolítica delimitou na Península Ibérica Medieval e as relações estabelecidas entre diferentes grupos étnico-religiosos, cristão, muçulmano e judeu, que os compartilharam.

$\mathrm{Na}$ esteira do ambiente histórico, abordamos algumas consequências desse contato interétnico nos falares correntes na região, àquela época, conforme descritas na literatura especializada em filologia românica (ELIA, 2004; LÜDTKE, 1974), e particularmente áraboromânica (VARGENS, 2007; CORRIENTE, 1996), em história da língua portuguesa (TEYSSIER, 2001; VASCONCELOS, 1956; SILVA NETO, 1988) e em história (CONSTABLE, 1997; THORAVAL, 1996; LEWIS, 1996; LE BON, 1974). Trata-se, portanto, de uma pesquisa bibliográfica.

O problema de investigação é: "O que informa a literatura especializada acerca do contato de línguas na Ibéria Medieval?" A hipótese testada é a de que a diglossia árabe-romance está fartamente documentada na literatura especializada no tema dos arabismos ibéricos medievais.

Justifica este estudo a sua fundamentação seja em obras de publicação mais recente, seja em obras em língua estrangeira, seja, ainda, em textos nem sempre disponíveis ou de fácil acesso, sobre tema obrigatório em aulas de filologia românica (o superstrato árabe) e de história da língua portuguesa (arabismos portugueses). 


\section{A Espanha e Alandalus}

\subsection{A conquista muçulmana}

O sul da Europa conheceu, na Idade Média, um invasor cuja fixação humana e linguística proporcionou, na Península Ibérica, uma colonização semelhante à que havia acontecido à época dos romanos, com a difusão de hábitos linguístico-culturais próprios, ainda que por meio de elemento humano aculturado.

Em 711, o general berbere islamizado Táriq Ibn Ziad invadiu a referida península, de onde os muçulmanos partiram somente nos séculos XIII, com a tomada de Faro (1253), no atual território Português, e XV, quando foram expulsos de Granada (1492), na Espanha. Pouco depois da chegada dos muçulmanos à Península Ibérica, no Oriente Médio verificouse o massacre da família omíada, que então governava o império árabe a partir de Damasco (661-750), e o deslocamento da sede do governo para Bagdá, realizado pela dinastia abássida (750-1258). O príncipe omíada, Abd Al Rahman, escapou ao massacre e procurou, em plagas distantes, um novo território onde pudesse exercer a sua soberania. Em 756, fezse proclamar emir em Alandalus, com capital estabelecida em Córdova, submetendo-a a intensa arabização, comparável à dos territórios orientais do mundo árabe (THORAVAL, 1996, p. 117, 118, 244-246).

Uma crônica escrita em latim, em 754 , por autor cristão anônimo, constitui um precioso testemunho dos primórdios da ocupação muçulmana da Península Ibérica. Apesar de expressar desagrado com relação a esta, não questiona a legitimidade dos governantes e, com efeito, relata a sua habilidade de gestão, sobretudo no que respeita à promoção da paz (CONSTABLE, 1997, p. 29).

Na Idade Média, portanto, a designação Espanha ( $<$ lat. Hispania) se referia à totalidade dos territórios ibéricos cristianizados, ao passo que o termo Alandalus era restrito exclusivamente à entidade política ali estabelecida com a chegada do invasor muçulmano (THORAVAL, 1996, p. 30). A literatura especializada na história medieval ibérica por vezes fala em Espanha Muçulmana, designação inconveniente por correlacionar dois elementos mutuamente excludentes: a Espanha é cristã; Alandalus, muçulmano.

No século IX, os reinos cristãos estavam confinados em diminuta faixa ao norte da península, entretanto, no século XII, já haviam tomado boa parte dos territórios sitos ao centro. Se as disputas territoriais eram frequentes, tendo início as guerras da Reconquista já no século VIII (com 
Pelágio, fundador do reino das Astúrias), em Alandalus, a conversão dos novos súditos não era incentivada, dada a arrecadação de um imposto de quem professasse fé diversa da muçulmana, a jizya.

Preservou-se, portanto, certa autonomia das comunidades cristã e judaica, que mantiveram suas escolas, templos e administradores. Também não se deu a imposição da língua árabe, a língua em que Alá teria se dirigido à humanidade e cuja aprendizagem, se não obrigatória, era ao menos desejável e recomendada para a leitura do Alcorão no original (MOLÉNAT, 1992, p. 85).

Observam-se, neste contexto, algumas semelhanças com a colonização romana:

a) a "tolerância" religiosa e linguística;"

b) a colonização verificada predominantemente por não árabes, efetuada, efetivamente, por homens oriundos de territórios islamizados, sobretudo do norte da África, a exemplo do próprio conquistador Táriq, um berbere;

c) a introdução na Península Ibérica do árabe clássico, o árabe de Meca dos primórdios do século VII, codificado desde o seu registro no Alcorão (612-632), mas sobretudo de variedades diatópicas/ diastráticas da língua árabe, norte-africanas e não padrão;

d) a realização de casamentos inter-raciais, com mulheres ibéricas, e a consequente formação de famílias bilíngues, falantes de árabe e romance (SILVA NETO, 1988, p. 333; LAPESA, 1991, p. 95).

Andrade Filho descreve a estrutura demográfica andalusina, apontando os muçulmanos como elemento minoritário, cujas diversificadas origens étnicas embasaram uma estratificação social que deu origem a conflitos sociais no seio da comunidade islâmica.

\footnotetext{
${ }^{1}$ Federico Corriente, atualmente o maior nome nos estudos dos arabismos ibéricos, desmitifica a convivência pacífica entre cristãos, muçulmanos e judeus, na Ibéria medieval, por muitos festejada. Com efeito, fala, antes, em genocídio. Segundo o autor, a intolerância se estenderia ao campo das investigações, levando os cientistas a se posicionarem com parcialidade ao abordarem a extensão do influxo arábicoislâmico nas línguas e nas culturas peninsulares (CORRIENTE, 1996, p. 4). Entretanto, Constable afirma ser a realidade ibérica mais complexa, uma vez que se verificavam hostilidades e alianças tanto entre governantes cristãos, como entre o rei de Castela e o de Portugal, quanto entre muçulmanos, a exemplo dos governantes de Córdova e de Saragoça (CONSTABLE, 1997, p. xxv).
} 
Apesar da rapidez com que foi conquistada, a península ibérica pouco se transformou com a instalação dos invasores a princípio. Estima-se que meio século após a invasão, os muçulmanos não fossem mais de sessenta mil. Essa limitação demográfica é confirmada por alguns fatos como, por exemplo, o recurso à utilização de mercenários e a não exploração direta de boa parcela das terras conquistadas. Mesmo se considerando a pequena tradição agrícola árabe, não era o que acontecia em outros locais. É certo que houve um fluxo mais ou menos contínuo de migrações berberes para Al-Andalus, especialmente na época dos almorávidas e almoadas. Apesar de ser difícil uma avaliação, parece que essas ondas berberes foram contrabalançadas pelas migrações cristãs para o norte da península. Também há que se considerar as conversões para o Islã, a miscigenação e outros mecanismos de crescimento da população muçulmana. Mesmo assim, sendo na época califal uma das regiões mais densamente povoadas da Europa, Al-Andalus é área controlada por uma minoria (ANDRADE FILHO, 1997, p. 36).

E ainda,

A história das primeiras décadas de Al-Andalus é marcada por um conjunto de conflitos entre os vencedores. Alguns são de origens tribais, como, por exemplo, os atritos entre os árabes. Estendiam-se assim para o islã ibérico as rivalidades da Arábia pré-islâmica. A estas projeções do antigo meio tribal, coloca-se o conflito étnico. Os berberes, numericamente superiores aos árabes, são por estes tratados como inferiores. [...] Em meio a essas "guerras civis", ainda intervêm elementos externos: tropas orientais, os chamados "sírios". [...] Derrotado o inimigo comum, retomam-se as rivalidades tribais. Complicando o quadro, alguns desentendimentos põem os antigos aliados "sírios" em atrito com os árabes. Estes últimos buscam então auxílio entre os berberes (ANDRADE FILHO, 1997, p. 35).

Da intensa convivência entre hispano-godos, berberes e alguns árabes (iemenitas, sírios) e do consequente processo de aculturação das populações nativas, verificado em Alandalus, decorrem antigas interferências linguísticas do árabe nos romances e nas línguas ibéricas, cuja antiga e completa integração às estruturas das línguas que os receberam dificulta a sua percepção enquanto elementos originalmente alógenos. 


\subsection{Os reinos cristãos}

Os reinos cristãos, à época da presença muçulmana na Península Ibérica, estendiam-se por estreita área montanhosa ao norte, na região das Astúrias e da Cantábria, onde se formaram os primeiros núcleos de resistência aos invasores: Astúrias, Castela-Leão, Aragão-Catalunha, Navarra e Portugal. A sua disposição geográfica é uma faixa horizontal.

A Figura 1 a seguir mostra a integração de cerca de dois terços da Península Ibérica no mundo arábico-islâmico, que se estende do Oriente Médio atual ao norte da África e à Península Ibérica, o chamado Ġarb, 'Ocidente' (CORRIENTE, 2003, s.v. algarvès).

Figura 1 - Emirado de Córdova no mundo árabe

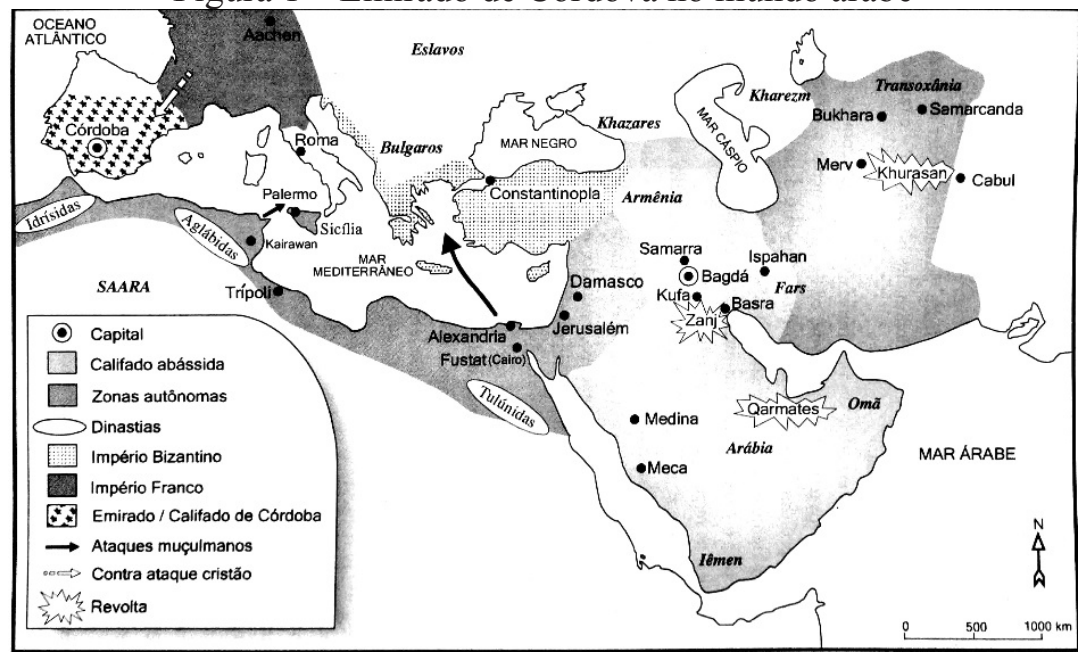

Fonte: DEMANT, 2005, p. 45.

Sucessivas investidas em direção ao sul, com o concurso de cavaleiros franceses cristãos, culminaram na conquista de territórios meridionais e no estabelecimento de reinos verticalizados, como hoje se definem as fronteiras de Portugal e da Espanha.

Esse processo de retomada dos territórios ibéricos sob jugo muçulmano, cunhado de Reconquista pela historiografia espanhola, foi fortemente favorecido pelo esfacelamento do Califado omíada de Córdova, em 1031, e pela sua substituição pelos reinos de taifas (do árabe taifa, 'partido, seita, facção'), política e militarmente mais frágeis: Málaga, Granada, Valença, Badajoz, Toledo, Sevilha, Saragoça, 
Malhorc, dentre outros (THORAVAL, 1996, p. 268-269, 288-289). O desmembramento de Alandalus nas taifas estendeu-se sempre pelas regiões central e meridional da península, do ocidente para o oriente.

\subsection{Os hispano-godos arabizados}

Entretanto, a população cristã de Alandalus, falante de romance, sob jugo muçulmano se aculturou, a ponto de preservar apenas a religião cristã e a língua românica, esta última fortemente marcada pelo contato com o árabe, notadamente o seu léxico e escrita, motivo pelo qual ficaram a língua e seus usuários conhecidos como moçárabes, cujo étimo é o árabe andalusino mustaSrabi, gentílico do árabe clássico mustaSrab, 'arabizado', contaminado pelo romance de origem latina imediata (CORRIENTE, 2003, s.v. moçárabe). Historiadores portugueses apontam o período entre os séculos VIII e XIII como aquele em que registros históricos dão notícia destes cristãos arabizados (CORRIENTE, 1996, p. 4-5; RIBEIRO, 1987, p. 42).

De acordo com Corriente, a arabização linguística e cultural dos hispano-godos cristãos se dá pelo prestígio da cultura arábico-islâmica.

[...] a ocupação islâmica de Alandalus fez surgir logo uma sociedade, embora gradualmente, bilíngue, com tendência à perda do romance, e islamizada, com uma tendência ainda mais rápida ao desaparecimento do cristianismo e do judaísmo. $\mathrm{O}$ prestígio da cultura arábico-islâmica tende a fazê-la exclusiva, imprimindo-lhe cristãos e judeus elementos substráticos que a matizam e diferenciam ocasionalmente de variantes orientais e norte-africanas, mas que é basicamente uma cultura arábicomuçulmana, por exemplo, nas artes e na estética, na indumentária, na culinária, na habitação e em aspectos da vida cotidiana, nos jogos e diversões, na administração, no comércio, na economia, etc. Na esfera privada do religioso se mantêm as diferenças, o que afeta muito pouco tempo da vida das pessoas, e, além disso, é, em muitos casos, tempo perdido, porque a maioria dos cristãos e judeus não entende nem o latim nem o hebraico dos ritos, ao passo que muitos deles [entendem] o árabe em que se dá o chamado para a oração islâmica nos minaretes próximos, ensinado em suas próprias escolas, quando a frequentam, e de que já necessitam em sua existência diária cada vez mais frequentemente, posto que 
existem atividades, se não grupos sociais, já monolíngues em árabe (CORRIENTE, 1996, p. 4-5, tradução minha). ${ }^{2}$

Com efeito, Menéndez Pidal recolheu, em documento da alta Idade Média, prova que corrobora tal posicionamento: em 854, Álvaro Cordovês se queixava da aculturação dos moçárabes, dentre os quais muitos falavam árabe e conheciam até mesmo a literatura produzida nesta língua, desconhecendo, por sua vez, a língua e a literatura latinas.

\begin{abstract}
Álvaro Cordovês, cujo Indiculus luminosos, escrito em 854, lamenta a grande desnacionalização que se difundia entre os moçárabes; os jovens cristãos adotavam até tal ponto os costumes dos dominadores, que se circuncidavam para evitar ofensas, e, apaixonados pela erudição muçulmana, só se deleitavam com os versos e as fábulas árabes, só liam os livros dos infiéis, de modo que, desconhecendo os textos latinos, esqueciam o próprio idioma: [...] em meio à gente de Cristo encontrarás apenas um entre mil que possa escrever razoavelmente uma carta a seu irmão, ao passo que há inúmeros que saberão declarar a pompa das vozes arábicas e que conhecem os primores da métrica árabe melhor que os infiéis (MENÉNDEZ PIDAL, 1950, p. 417-418, tradução minha, destaque do autor). ${ }^{3}$
\end{abstract}

2 “[...] la ocupación islámica supuso en Alandalús la aparición de una sociedad pronto aunque gradualmente bilingüe con una tendencia a la pérdida del romance, e islamizada con una tendencia aún más rápida a la desaparición de cristianismo y judaísmo. El prestigio de la cultura arábigo-islámica tiende a hacerla exclusiva, por lo que cristianos y judíos le aportan tan sólo algunos elementos sustráticos que la matizan y diferencian ocasionalmente de variantes orientales o norteafricanas, pero en todo lo básico es siempre eso, una cultura arábigo-islámica, vgr., en las artes y la estética, la indumentaria, cocina, vivienda y aspectos de la vida cotidiana, juegos y diversiones, administración, comercio, economía, etc. En la esfera privada de lo religioso se mantienen las diferencias, pero ello afecta muy poco tiempo de la vida de las personas, y es en muchos casos además tiempo muerto, porque la inmensa mayoría de cristianos y judíos no entienden el latín ni el hebreo de los ritos, y sí, en cambio, al menos y pronto muchos de ellos, el árabe en el que suena la llamada a la oración islámica en los cercanos minaretes, que se les enseña en sus propias escuelas, cuando van a ellas, y puesto que existen actividades, so no grupos sociales, ya monolingües en árabe".

3 "Álvaro Cordobés, cuyo Indiculus luminosos, escrito en 854, lamenta la gran desnacionalización que cundía entre los mozárabes; los jóvenes cristianos adoptaban hasta tal punto las costumbres de los dominadores, que se circuncidaban por evitar 
Conforme Corriente, o iberorromance foi, no contexto bilíngue andalusino, a língua utilizada pelos registros baixos, em contextos menos formais de comunicação, como língua de menor prestígio social, face ao árabe.

Na Península Ibérica, focando agora nos aspectos linguísticos, a verdade é que a ocupação islâmica levou ao aparecimento de uma sociedade logo, ainda que gradualmente, bilíngue, com uma tendência à perda do romance, e islamizada, com uma tendência ainda mais rápida ao desaparecimento do cristianismo e do judaísmo (CORRIENTE, 1996, p. 4, tradução minha). ${ }^{4}$

Conheceu Alandalus diferentes fases em sua história, aqui apenas citadas. Além da sua fragmentação nos reinos de taifas, houve duas dinastias norte-africanas, almorávida (1056-1147) e almôada (11301269), que promoveram a intolerância religiosa e deslocamentos maciços: deportações, imigrações voluntárias, para o norte da África ou da própria Península Ibérica.

Estes fatos da história política da região tiveram importantes desdobramentos na evolução das línguas peninsulares, uma vez que colocou em contato línguas e dialetos diversos, a que se seguiu a natural interferência intersistêmica (MENÉNDEZ PIDAL, 1950, p. 416, 425426, 430; MOLÉNAT, 1992, p. 84).

\section{Espaços linguístico-culturais na Península Ibérica Medieval}

\subsection{Os domínios linguísticos da Península Ibérica Medieval}

A queda do Império Romano do Ocidente, em 476, levou à fragmentação política da antiga província da Hispanĭa em vários reinos germânicos, encabeçados, nesta região, por visigodos, vândalos, alanos e

denuestos, y enamorados de la erudición musulmana, sólo se deleitaban en los versos y las fábulas árabes, sólo leían los libros de los infieles, así que, desconociendo los textos latinos, olvidaban el proprio idioma: [...] en la gente de Cristo apenas hallarás uno entre mil que pueda escribir razonablemente una carta a su hermano, $y$, en cambio, los hay innumerables que os sabrán declarar la pompa de las voces arábigas y que conocen los primores de la métrica árabe mejor que los infieles".

4 "En la Península Ibérica, y ciñéndonos ahora a los aspectos lingüísticos, la verdade es que la ocupación islámica suposo en Alandalús la aparición de una sociedad pronto aunque gradualmente bilingüe con una tendencia a la pérdida del romance, e islamizada con una tendencia a la desaparición de cristianismo y judaísmo". 
suevos, latinizados e cristianizados, o que facultou a dialetação do sermo hispanicus em romances diversos (VASCO DA GAMA, 1995, p. 42, 48-49).

Temos, portanto, na Antiguidade, o latim hispânico e, na Idade Média, o romance, termo originado no advérbio latino romanice (do latim tardo romanǐce, 'ao modo de Roma'), ou seja, um falar relacionado ao latim, mas com o qual já não mais se confunde (BASSETTO, 2001, p. 185). Testemunha a impossibilidade de o falante de romance compreender o latim a orientação da Igreja Católica de se realizar a homilia na língua popular, o romance, para garantia da cristianização das massas, em decisão do Concílio de Tours, realizado em 813 (VASCO DA GAMA, 1995, p. 48; BASSETTO, 2001, p. 185). Na Idade Média ibérica, portanto, vamos encontrar romances usados cotidianamente, ao lado do latim da instrução, das ciências e da religião, o latim medieval, latim este que já não é língua materna de ninguém (BASSETTO, 2001, p. 171-173). ${ }^{5}$

Por força da história política, econômica, social e cultural dos diferentes reinos ibéricos, os romances peninsulares evoluídos do latim hispânico terão evoluções distintas. Grosso modo, há, ao norte, romances de pequenos reinos cristãos, além do basco, falado em território nunca sequer romanizado. Já no centro e no sul da Península Ibérica, há diferentes variedades do romance meridional, o romance andalusino ou romandalusino, cuja designação de língua moçárabe Corriente (1996, p. $5,8)$ julga inadequada, pela falsa associação a que induz à comunidade cristã, uma vez que é de uso generalizado, o vernáculo de todos os habitantes de Alandalus, incluindo-se entre os seus falantes os judeus e mesmo os muçulmanos. Como adstrato, figura o árabe andalusino,

${ }^{5} \mathrm{O}$ latim medieval irá sofrer tantas interferências morfossintáticas e lexicais dos romances e das demais línguas maternas de seus usuários que o classicismo promoverá a sua "depuração', a partir de estudos pautados na documentação latina remanescente nos monastérios, frequentemente por intermédio dos monges copistas. Assim, surgirá o latim renascentista, subjacente ao latim científico do século XVIII, em uso até hoje, por exemplo, na biologia e na matemática (BETTS, 2003, p. 6-7). Essa observação figura, aqui, apenas como exemplo da natural interferência que os sistemas linguísticos exercem uns sobre os outros, na mente de usuários bilíngues. Lembremos, ainda, que o uso do latim, na Idade Média, extrapola o espaço da România Medieval, conjunto dos territórios outrora integrantes do Império Romano, nos quais o latim suplantou línguas autóctones, tornando-se a língua da comunicação cotidiana (BASSETTO, 2001, p. 179181). Nesse período, o latim é a língua da erudição também nos domínios linguísticos europeus germânicos, eslavos, etc. 
"aclimatação" do árabe dialetal norte-africano na Península Ibérica islamizada, em contato com os demais idiomas ali falados.

A Figura 2 demonstra a distribuição dos romances ibéricos no século X. A área romandalusina (moçárabe) se estende pelo domínio político de Alandalus, portanto, por extensa área da Península Ibérica. As línguas cristãs se restringem ao norte peninsular.

Figura 2 - Domínios linguísticos ibéricos no século X

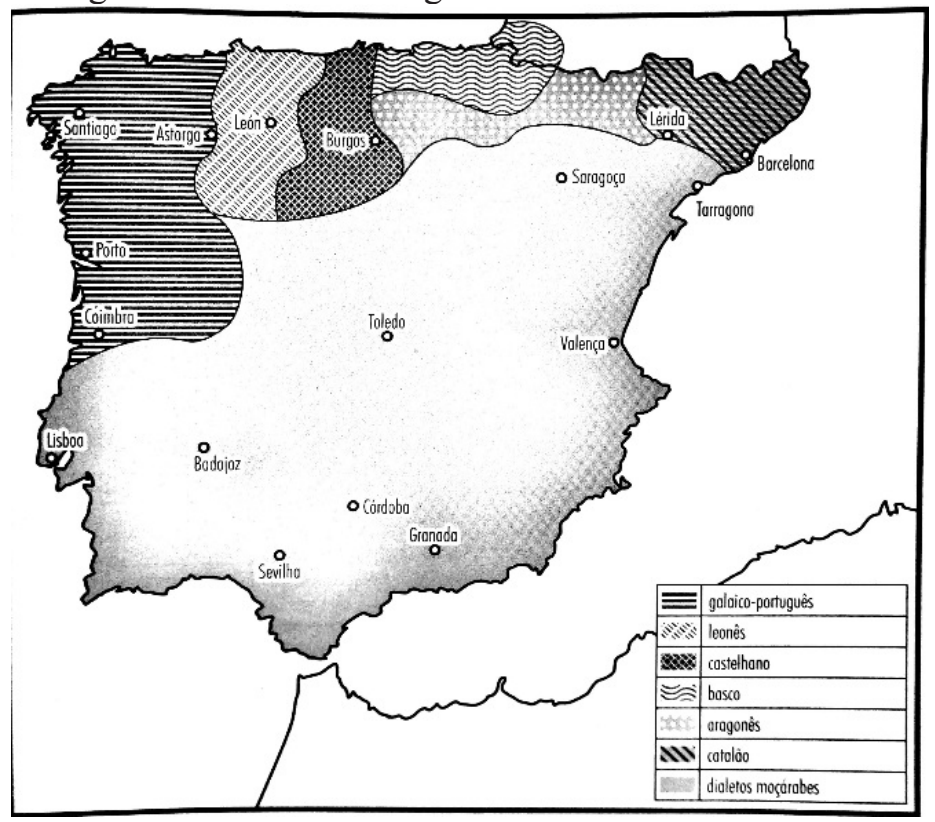

Fonte: ENTWISTLE, 1948 apud ILARI, 2018, p. 177.

Constable descreve o uso alternado, oral e escrito, de línguas distintas pelas comunidades cristã, muçulmana e judaica, a partir da sua experiência com documentação remanescente do período.

Da mesma forma, estes textos medievais foram escritos em muitas línguas diferentes. Cristãos escreveram em latim e, depois, em romances vernáculos, inclusive em castelhano, catalão, português e galego. Os muçulmanos geralmente escreveram em árabe, embora os mudêjares (muçulmanos que viviam sob jugo cristão na baixa Idade Média) paulatinamente tenham criado o aljamiado, uma versão do romance vernacular grafado com caracteres árabes. Alguns cristãos 
também usaram o árabe, particularmente se moçárabes (cristãos arabizados vivendo sob jugo muçulmano). Similarmente, judeus que habitavam a Espanha muçulmana frequentemente escreveram em árabe (ou judeu-árabe, uma versão do árabe grafado com caracteres hebraicos), especialmente em documentos seculares, mas sua língua literária e religiosa era fundamentalmente o hebraico (CONSTABLE, 1997, p. xxvi, tradução minha) ${ }^{6}$

\section{Ao que Constable acrescenta:}

A língua era o principal instrumento de identidade e de segregação, diferenciando uma comunidade da outra, apesar de ser também um meio de comunicação, uma maneira de transpor as fronteiras das comunidades. Muitos se sentiam à vontade em mais de uma língua e era normal as pessoas letradas escreverem em uma língua, enquanto usassem outra na conversação cotidiana. Por exemplo, um mercador judeu na Espanha muçulmana devia falar geralmente árabe com os seus clientes e familiares e provavelmente também um dialeto românico, quando necessário; ter-se-ia correspondido em judeu-árabe com parceiros de negócios, mas teria usado o hebraico para assuntos religiosos em casa e na comunidade judaica (CONSTABLE, 1997, p. xxvi, tradução minha). ${ }^{7}$

\footnotetext{
6 "Likewise, these medieval texts were written in many different languages. Christians wrote in Latin and in Romance vernaculars, including Castilian, Catalan, Portuguese, and Galician. Muslims generally wrote in Arabic, though the Mudejars (Muslims living under Christian rule in the later Middle Ages) gradually created Aljamiado, a version of the Romance vernacular written in Arabic characters. Some Christians also used Arabic, particularly if they were Mozarabs (Arabized Christians, usually living under Muslim rule). Similarly, Jews living in Muslim Spain often wrote in Arabic (or Judeo-Arabic, a version of Arabic written in Hebrew characters), especially for secular documents, but their primary literary and religious language was Hebrew".

7 " "Language was a primary tool of identity and segregation, marking off one community from another, yet it was also a means for communication, a way of crossing boundaries between communities. Many people were comfortable in more than one language, and it was normal for literate people to write in one language while using another for everyday conversation. For example, a Jewish merchant in Muslim Spain might generally have spoken Arabic with his clients and family, and probably also a Romance dialect when needed; he would have corresponded with business partners in Judeo-Arabic, but would have used Hebrew for religious matters at home and in the Jewish Community".
} 
Esse manejo de línguas distintas extrapolava as classes socioeconômicas mais abastadas. De acordo com Soler,

Coexistia o arábico puro junto com o latim vulgar, também chamado de língua romance, bilinguismo que era, não apenas próprio das camadas altas, como também das humildes. Conta o historiador Mariano que, durante o sítio de Calatanazor, um pobre pescador cantava, alternadamente em língua vulgar e em língua árabe, um lamento sobre o triste destino da cidade sitiada (SOLER, 1995, p. 32). ${ }^{8}$

O Oriente testemunha o bilinguismo em Alandalus por intermédio, dentre outros, de um viajante da segunda metade do século X, o qual nunca estivera no Ocidente, mas diz saber que ali "a língua falada era árabe, mas obscura e de difícil compreensão, e há ainda outra língua semelhante ou relacionada com a latina", assim como botânicos andaluzes, ao descreverem as plantas, davam-lhes seus nomes árabes, mas acrescem a estes o nome correspondente em aljamia (MENÉNDEZ PIDAL, 1950, p. 423, 427-428). No contexto ibérico, o termo aljamia corresponde à língua estrangeira escrita em caracteres árabes (VARGENS, 2007, p. 115) e algaravia, tanto à língua árabe, quanto, figurativamente, à linguagem desconhecida, ininteligível e, por extensão, à coisa de difícil entendimento (VARGENS, 2007, p. 110).

A Figura 3 abaixo mostra a redução territorial de Alandalus, restrita, no século XIII, ao Reino de Granada, com a consequente expansão das línguas ibéricas nortenhas em direção ao sul peninsular.

\footnotetext{
${ }^{8}$ Lembramos apenas que o conceito de língua pura não existe, uma vez que qualquer língua é constituída por conjuntos de variedades - históricas, geográficas, sociais (de gênero, idade, profissão, nível de escolarização, etc.), além da variedade de situação ou de contexto (mais ou menos formal) de comunicação - e está sujeita a contínuas transformações, dentre outros motivos, pelo contato com outras línguas. Provavelmente, o que o autor quis dizer é que o pescador falasse árabe como "língua plena", conforme designa a linguística de contato, e não como um pidgin, isto é, como uma "variedade simplificada" para interação de falantes de línguas maternas distintas.
} 
Figura 3 - Domínios linguísticos ibéricos ao final do século XIII

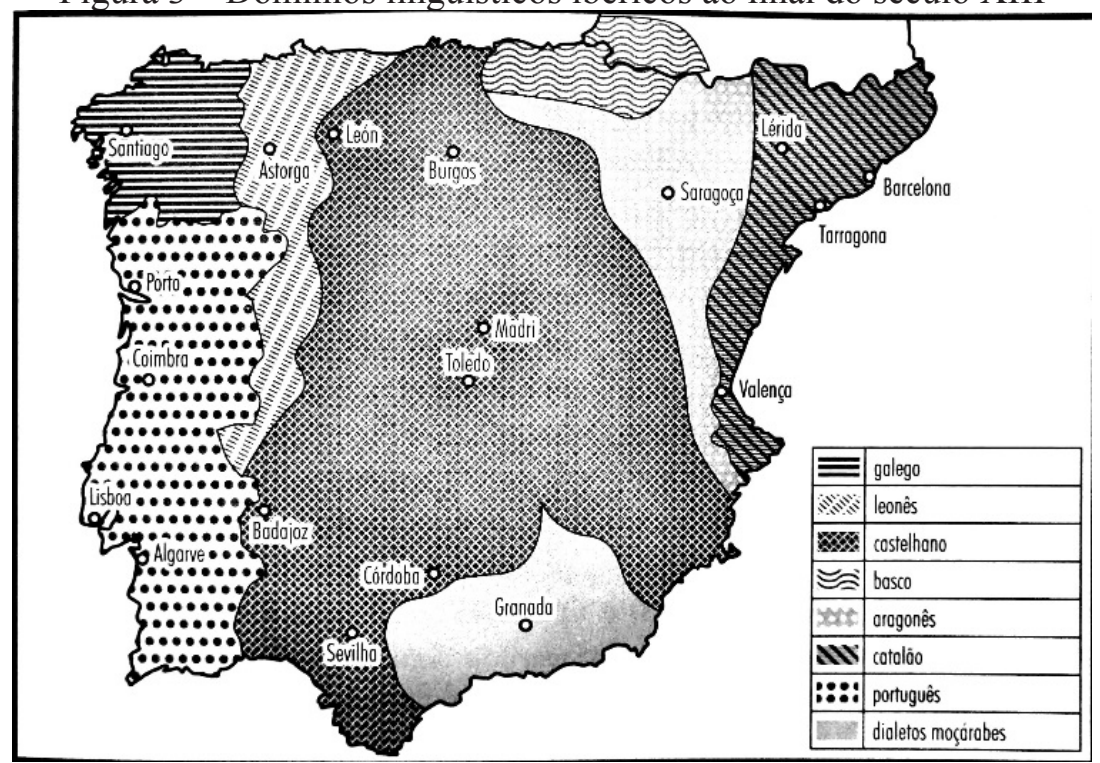

Fonte: ENTWISTLE, 1948 apud ILARI, 2018, p. 179.

O latim e o árabe clássico eram, à época, línguas de prestígio, empregadas nos âmbitos da religião e da cultura erudita. Não trataremos, neste estudo, das línguas empregadas pelos judeus, embora o judeuespanhol tenha tido importantes desdobramentos, por exemplo, na Turquia e nos Marrocos (SEPHIHA, 1997, p. 1).

Segundo Lüdtke (1974, p. 243), a diglossia ou "bilinguismo social" decorre do uso alternado de um dialeto e de uma língua de cultura codificada. Considerando-se o depoimento de Álvaro Cordovês, datado de meados do século IX, sobre a aculturação dos hispano-godos cristãos, encantados com a língua e a cultura árabes, e a observação de Corriente (1996, p. 4-5) sobre a restrição do uso do romance cristão de Alandalus a situações menos formais de comunicação, conclui-se ter havido diglossia no contexto político-cultural islamizado em que viveram os moçárabes no território ibérico muçulmano.

\subsection{Contatos linguístico-culturais, interferência e arabismos lexicais}

Os moçárabes, hispano-godos cristãos, cultural e linguisticamente arabizados, exerceram importante papel na difusão da cultura arábicomuçulmana, nos reinos cristãos peninsulares. 
[...] Em Alandalus, só há essa única cultura arábico-islâmica, tão prestigiada que os próprios estados cristãos incipientes do norte, consciente ou inconscientemente, imitam-na em quase todos os seus aspectos seculares, graças à mediação dos imigrantes moçárabes que, precisamente por conhecê-la a fundo, garantiram o êxito social que refletem, por exemplo, os estudos de Gómez Moreno (CORRIENTE, 1996, p. 5, tradução minha). ${ }^{9}$

Acresce, então, a transmissão de arabismos aos romances ibéricos nortenhos, promovida por este segmento da sociedade andalusina:

São, por conseguinte, os moçárabes emigrados ao norte os que, possuidores, como inevitável corolário da derrota e a forçada convivência, da cultura arábico-islâmica e seus conceitos inexistentes e inominados em romance, introduzem neste os arabismos que os denominam (CORRIENTE, 1996, p. 5, tradução minha)..$^{10}$

Silva (2003), Teyssier (2001, p. 22) e Vasconcelos (1956, p. 299) veem no contato prolongado, durante a Idade Média, e no refinamento cultural do conquistador muçulmano, que concorreu para a evolução das ciências, das técnicas e das artes mais variadas, em solo ibérico, a interferência do árabe no desenvolvimento das línguas ali em uso. No dizer de Paul, "uma forte influência civilizatória leva quase invariavelmente a uma larga importação de vocábulos estrangeiros" (PAUL, 1970, p. 460, tradução minha). ${ }^{11}$

De acordo com Le Bon,

a civilização muçulmana teve uma influência imensa no mundo e [...] esta influência se deve tão somente aos árabes e não às diversas raças que adotaram o seu culto. Com a sua influência moral, civilizaram os

\footnotetext{
9 “En Alandalús sólo hay esa única cultura arábigo-islámica, además tan prestigiosa que los mismos incipientes estados cristianos del Norte consciente o inconscientemente la imitan en casi todos sus aspectos seculares, gracias a la mediación de los inmigrantes mozárabes que, precisamente por conocerla a fondo, tuvieron garantizado el éxito social que reflejan, vgr., los estudios de Gómez Moreno".

10 "Son, por conseguiente, los mozárabes ya emigrados al Norte los que, poseedores, como inevitable corolario de la derrota y la forzada convivencia, de la cultura arábigoislámica y sus conceptos inexistentes e innominados en romance, introducen en él los arabismos que los dominan".

11 "A strong civilising influence entails almost invariably a large importation of foreign word".
} 
povos bárbaros que tinham destruído o Império Romano; com a sua influência intelectual, abriram à Europa o mundo dos conhecimentos científicos, literários e filosóficos de que não tinha a menor ideia, e durante 600 anos foram nossos civilizadores e professores (LE BON, 1974, p. 508, tradução minha). ${ }^{12}$

E ainda:

A barbárie na Europa foi por muito tempo demasiadamente grande para que os europeus conseguissem ver o seu estado e apenas no século XI e particularmente no XII surgiram algumas tendências científicas. Quando algumas inteligências, mais perspicazes, reconheceram a necessidade de sacudirem aquela ignorância, pediram auxílio aos árabes, que eram então os únicos professores (LE BON, 1974, p. 496-498, tradução minha). ${ }^{13}$

\section{Ao que continua:}

Assim, portanto, não é correto que, conforme alguém disse, as ciências chegaram à Europa graças às cruzadas, o correto é que chegaram pela Espanha, pela Itália e pela Sicília. Já em 1130 uma escola de tradutores, fundada em Toledo, sob a proteção do bispo Raimundo, começou a tradução dos mais célebres autores árabes para o latim. O êxito destas traduções foi ressonante. Com elas se abriu um novo mundo para o Ocidente e, durante os séculos XII, XIII e XIV, o trabalho dos tradutores não parou, vertendo para o latim Arrasí, Abu Kasim, Avicena, Averróis, mas também autores gregos como Galeno, Hipócrates, Platão, Aristóteles, Euclides, Arquimedes e Ptolomeu, que os muçulmanos haviam traduzido para a sua própria língua. Na sua História da Medicina Árabe, o

12 “[...] la civilización musulmana tuvo en el mundo una influencia inmensa, y [...] esa influencia se debe a los árabes tan sólo, y no a las razas diversas que han adoptado su culto. Con su influencia moral han civilizado a los pueblos bárbaros que habían destruído el imperio romano; con su influencia intelectual abrieron a Europa el mundo de los conocimientos científicos, literarios y filosóficos de que no tenía la menor idea, y ellos han sido durante 600 años nuestros civilizadores y maestros".

13 "La barbarie de Europa fué mucho tempo demasiado grande para que los europeus echasen de ver su estado; y tan solo en el siglo XI y particularmente em el XII aparecieron algunas tendencias científicas. Cuando algunas inteligencias, algo perspicaces, reconocieron la necesidad de sacudir aquella ignorancia, pidieron auxilio a los árabes, que entonces eran los únicos maestros". 
dr. Leclerc aumenta para mais de 300 o número de obras árabes traduzidas para o latim. O fato é que a Idade Média não conheceu a Antiguidade grega, a não ser depois que esta passou para a língua dos discípulos do profeta. Graças às traduções, algumas obras antigas, cujos originais se tinham perdido, puderam chegar até nós, por exemplo, as cônicas de Apolônio, os comentários de Galeno sobre as epidemias, o tratado das pedras, de autoria de Aristóteles, etc. Sim, aos árabes se deve o conhecimento da Antiguidade, não se deve aos frades da Idade Média, os quais ignoravam até o grego, e por isso devemos àqueles uma gratidão eterna por ter-nos salvado tão precioso tesouro. "Apaguem os árabes da história", diz Libri, "e o renascimento das letras tardará ainda muito séculos na Europa" (LE BON, 1974, p. 496-498, tradução minha). ${ }^{14}$

\section{No que diz respeito à Economia, muito se deve à presença muçulmana na Península Ibérica. De acordo com Lewis,}

O Islão espanhol, no seu apogeu, ofereceu um espetáculo soberbo. Os árabes enriqueceram a vida da Península de muitas maneiras: na agricultura introduziram a irrigação científica e muitas novas culturas, incluindo citrinos, algodão, cana-de-açúcar e arroz. As

\footnotetext{
${ }^{14}$ Así pues, no es certo, según se há dicho, que las ciencias penetrasen en Europa merced a las cruzadas; lo certo es que penetraron por España, Italia y Sicilia. Ya em 1130 un colegio de traductores, fundo em Toledo, bajo el protectorado del obispo Raimundo, comenzó en latín la tradución de los más célebres autores árabes. El éxito de estas traducciones fué ressonante. Con ellas se abrió un mundo nuevo al Occidente; y durante los siglos XII, XIII y XIV el trabajo de las traducciones no cesó, poniendo en latín no sólo a Arrazí, a Abil Qâsim, Avicena, Averroes, sino también a los autores griegos, como Galeno, Hipócrates, Platón, Aristóteles, Euclides, Arquímedes y Ptolomeu, que los musulmanes habían vertido a su propia lengua. Em su Historia de la medicina árabe el Dr. Lecrerc hace ascender a más de 300 el número de obras árabes traducidas al latín. El hecho es que la Edad Media no conoció la antigüedad griega, sino después que ésta pasó a la lengua de los discípulos del profeta. Gracias a las traducciones, algunas antiguas obras, cuyos originales se han perdido, han podido llegar hasta nosotros, como por ejemplo, las secciones cónicas de Apollonio, los comentarios de Galeno sobre las epidemias, el tratado de las piedras por Aristóteles, etc. Sí, a los árabes se debe el conocimiento de la antigüedad; no se debe a los frailes de la Edad Media, los cuales hasta el griego ignoraban; y por eso debemos a aquéllos una gratitud eterna por habernos salvado tan precioso tesoro. "Borrad a los árabes de la historia", disse Libri, "y el renacimiento de las letras tardará aún muchos siglos en Europa".
} 
alterações que operaram no regime da propriedade rural foram grandemente responsáveis pela situação próspera da agricultura espanhola sob o domínio árabe. Desenvolveram inúmeras indústrias - têxteis, faiança, papel, seda e refinação de açúcar, e exploraram importantes minas de ouro, prata e outros metais. A lã e a seda eram fabricadas em Córdova, Málaga e Almeria, a faiança em Málaga e Valência, armas em Córdova e Toledo, trabalhos de couro em Córdova, tapetes em Beza e Cálcena, papel - importação árabe do extremo Oriente - em Jativa e Valência. Tal como no Islão, os têxteis constituíram a principal indústria, e ouvimos falar de 13000 tecelões só em Córdova. A Espanha muçulmana desenvolveu um largo comércio com o Oriente, e as frotas mercantes dos portos andaluzes transportavam os produtos espanhóis por todo o Mediterrâneo. Os principais mercados situam-se no Norte da África sobretudo no Egito, e em Constantinopla, onde os mercadores bizantinos compravam os seus produtos para os venderem na Índia e Ásia central [...] (LEWIS, 1996, p. 143-144).

Com efeito, Corriente aponta consequências linguísticas da posição de língua de menor prestígio, como na situação de bilinguismo verificada em Alandalus:

O ibero-romance, pois, desde o sul culturalmente arábicoislâmico, apesar de um bilinguismo em que o romance ocupa a posição de língua dominada para registros baixos recebeu: a) alguns poucos arabismos [...], b) muitos andalusismos, c) bastantes romancismos meridionais [...] e d) vozes híbridas áraberomances, todos matizes que devem ser considerados ao se estudar esta questão (CORRIENTE, 1996, p. 5-6, tradução minha). ${ }^{15}$

Constituindo a necessidade designativa a causa mais frequente da importação de material léxico estrangeiro, a atenta observação dos campos semânticos em que se enquadram permite, portanto, conhecer a natureza

\footnotetext{
15 “El iberorromance, pues, desde el Sur arábigo-islámico, a pesar de un bilingüismo en el que el romance ocupa la posición de lengua dominada para los registros bajos, ha recibido: a) algunos pocos arabismos cultos [...], b) muchos andalusismos, c) bastantes romancismos meridionales [...] e voces híbridas arábigo-romances, matices todos ellos que deben tenerse en cuenta al estudiar esta cuestión".
} 
dos referentes adquiridos no contato cultural, quando comunidades de culturas (e, em geral, de línguas maternas) distintas passam a interagir.

Lewis aborda a contribuição lexical árabe para as línguas peninsulares:

As inúmeras expressões árabes que subsistem na agricultura e nas artes e ofícios ilustram a força da influência árabe. Mesmo na vida política, os múltiplos vocábulos árabes ainda em uso da língua espanhola, na administração local e no vocabulário militar, atestam a persistência da tradição árabe. O rei cristão do século XIV que mandou restaurar o Alcácer de Sevilha celebrou a sua obra com uma inscrição em árabe, "Glória ao nosso Soberano, o Sultão Dom Pedro". As moedas da reconquista conservaram o padrão árabe durante muito tempo (LEWIS, 1996, p. 144).

Abrangendo vários aspectos da vida cotidiana, os arabismos ibéricos, de aquisição antiga, ainda no período formativo da língua portuguesa, estão integrados de tal forma no sistema lexical desta que os seus falantes frequentes vezes sequer supõem a sua origem médio-oriental.

Abundantes vestígios materiais testemunham o influxo cultural muçulmano que se produziram na Península Ibérica, a exemplo da música e da dança, da literatura, do direito, do vestuário, da alimentação, da arquitetura e do urbanismo, da agricultura, do artesanato e das tradições (ALVES, 1999, p. 5-8).

Todavia, e lamentavelmente, continua por fazer o balanço etnográfico e cultural da presença árabe-berbere e islâmica no nosso país. [...] A mera avaliação dos sinais dessa presença, em face de ideias estafadas e de há séculos repetidas, minimizando o impacto islâmico, é no mínimo perturbadora. Discorrendo ao acaso, evidenciar-se-á: - Uma Ancestralidade semítica e berbere. Esta remonta a tempos pré-históricos e aquela provém da remota presença fenícia e cartaginesa que a pesquisa arqueológica e a análise de estruturas antropológicas não cessam de pôr em evidência [...] (ALVES, 1999, p. 5).

No que concerne às línguas peninsulares, o avanço técnicocientífico e artístico-cultural dos povos islamizados, durante a Idade Média ocidental, levou à adoção de numerosos arabismos pelos falares ibéricos, nos mais variados campos, como ilustram os exemplos portugueses a seguir, colhidos em Elia (2004, p. 107), Houaiss (1986), 
Silva (2003), Silva Neto (1988, p. 333), Teyssier (2001, p. 22), Vargens (2007, p. 221-225) e Vasconcelos (1956, p. 301-302):

a) técnicas e produtos agrícolas: açude, almuinha, safra, sega, açúcar, café, tamarindo;

b) guerra e vida militar: alferes, algema, almirante, arrais, arsenal, bodoque, calibre, refém;

c) indústria e comércio: açougue, alambique, armazém, azenha, azêmola, tara;

d) administração e finanças: aduana, alfândega, alvará, aval, leilão, tarifa;

e) profissões: açougue, alfaiate, almoxarife, magarefe;

f) ciências, técnicas e artes: algarismo, álgebra, zero, achaque, elixir, enxaqueca, писа, xarope, alquimia, alaúde, atabaque, atambor, axabeba, cifra;

g) vestuário: alpercata, babuche;

h) alimentação e culinária: almôndega, cuscuz, escabeche;

i) compartimentalização espacial e acidentes geográficos: aldeia, arrabalde, bairro, rincão;

j) habitação e vida doméstica: alcova, alicerce, almofada, andaime, azulejo, chafariz, divã, saguão, sofá, taça, taipa;

k) fauna (inclusive pesca): anta, atum, gazela, girafa;

1) jogos: xadrez;

m) religião: imame, ulemá, mussurumim, islame, jihad, mesquita, minarete, moçafo, tecebá.

A diversidade de campos semânticos em que se verificam os arabismos resulta da interação intergrupal ao longo de muitos séculos, com aquisição de elementos culturais arábico-islâmicos pelos falantes do romance lusitano e da língua portuguesa: o conhecimento técnico e científico, a construção civil, o urbanismo, a administração pública e o comércio são áreas em que os tecnicismos pululam; conflitos militares estão representados na terminologia da guerra e a vida social se vê arabizada no modo de vestir, no interior das casas e na alimentação. Da 
convivência com muçulmanos decorreu a importação de empréstimos do campo religioso.

No que respeita ao número desses arabismos portugueses, Vargens (2007) dicionariza mais de três mil lexias, entre arabismos ibéricos, incluindo os seus usos no português brasileiro, arabismos malês e síriolibaneses, próprios da sócio-história do Brasil (VIGUERA MOLINS apud VARGENS, 2007, orelha).

\section{Considerações finais}

Uma vez compreendido o ambiente linguístico da Península Ibérica na Idade Média, caracterizado como multilinguístico, coexistindo diversas variedades de romances (alçados posteriormente a línguas nacionais, identificadas pelos respectivos adjetivos pátrios), dialetos árabes e normas padrão escritas do latim, do árabe e do hebraico, a interferência de um sistema sobre o(s) outro(s) é natural, dando-se na mente dos falantes bilingues.

Com efeito, a literatura sobre contato de línguas na região, no medievo, ratifica o uso alternado de sistemas linguísticos diversos pelos peninsulares, com os romances muitas vezes empregados em contextos familiares ou informais de comunicação.

A posição privilegiada dos muçulmanos, como conquistadores, detentores do poder político e econômico, cujo desenvolvimento técnico, científico, industrial e cultural, àquela altura, é inegável, suscita a transmissão de numerosos arabismos aos falares locais. Em decorrência da prolongada duração e da intensidade do contato, o número destes empréstimos é significativo, extrapolando os três milhares, e a profusão de campos semânticos em que se verificam testemunha as diversas áreas em que a interferência cultural se fez sentir.

$\mathrm{O}$ que se pretendeu neste artigo, e constitui de fato o problema de investigação, foi colher na literatura especializada "depoimentos" desse multilinguismo ibérico medieval. A hipótese de trabalho, sobre a documentação da diglossia árabe-romance, foi corroborada, dada esta realidade linguística ter sido documentada à época e ser sistematicamente retomada na literatura especializada em filologia (árabo-)românica, em histórias das línguas ibéricas (e, consequentemente, da língua portuguesa) e em história.

\section{Referências}


ALVES, A. Portugal: ecos de um passado árabe. Lisboa: Instituto Camões, 1999.

ANDRADE FILHO, R. Os muçulmanos na Península Ibérica. 3. ed. São Paulo: Contexto, 1997.

BASSETTO, B. F. Elementos de filologia românica: história externa das línguas. São Paulo: Edusp, 2001. v. 1.

BETTS, G. Latin. London: Hodder Education, 2003.

CONSTABLE, O. R. (Ed.). Medieval Iberia: readings from Christian, Muslim, and Jewish sources. 3. ed. Pennsilvania: University of Pennsilvania Press, 1997.

CORRIENTE, F. Diccionario de arabismos y voces afines en iberorromance. 2. ed. ampl. Madrid: Gredos, 2003.

CORRIENTE, F. Novedades en el estudio de los arabismos en iberorromance. Disponível em: <https://is.muni.cz/el/1421/jaro2012/ SJIIB966/um/7952570/26-1-Corriente_Arabismos_en_iberromance. pdf>. Acesso em: 28 fev. 2016.

DEMANT, P. O mundo muçulmano. 2. ed. São Paulo: Contexto, 2005.

ELIA, Sílvio. Preparação à linguística românica. Rio de Janeiro: Ao Livro Técnico, 2004.

HOUAISS, A. As projeções da língua árabe na língua portuguesa. Disponível em: $<$ http://www.hottopos.com/collat7/houaiss.htm>. Acesso em: 15 nov. 2006.

ILARI, R. Linguística Românica. 2. ed. São Paulo: Contexto, 2018.

LAPESA, R. Historia de la lengua española. 5. ed. Madrid: Escelicer.

LE BON, G. La civilización de los árabes. Versión española de Luís Carreras. 4. ed. Buenos Aires: El Nilo, 1974.

LEWIS, B. Os árabes na história. 2. ed. Lisboa: Estampa, 1996.

LÜDTKE, H. Historia del léxico románico. Versión castellana de Marcos Martínez Hernández. Madrid: Gredos, 1974.

MENÉNDEZ-PIDAL, R. Orígenes del español: estado lingüístico de la Península Ibérica hasta el siglo XI. 3. ed. muy corregida y adicionada. Madrid: Espasa Calpe, 1950. 
MOLÉNAT, J.-P. Os moçárabes: um exemplo de integração. In: CARDILLAC, Louis (Org.). Toledo, séculos XII e XIII: muçulmanos, cristãos e judeus: o saber e a tolerância. Tradução de Lucy Magalhães. Rio de Janeiro: Zahar, 1992. p. 83-98.

PAUL, H. Principles of the history of language. Translated from the second edition of the original by H. A. Strong. Maryland: McGrath, 1970.

RIBEIRO, O. A formação de Portugal. Lisboa: Instituto de Cultura e Língua Portuguesa, 1987.

SEPHIHA, H.-V. Judeo-Spanish. Disponível em: <http://michel.azaria. free.fr/History.htm>. Acesso em: 5 mar. 2016.

SILVA NETO, S. da. História da língua portuguesa. Rio de Janeiro: Presença, INL, 1988.

SILVA, R. V. M. Empréstimos culturais no período arcaico da língua portuguesa. Disponível em: <http://www.prohpor.ufba.br/esprescultu. html>. Acesso em: 5 fev. 2003.

SOLER, L. Origens árabes no folclore do sertão brasileiro. Florianópolis: EDUFSC, 1995.

TEYSSIER, P. O português europeu: do século XIV aos nossos dias. In: . História da língua portuguesa. Tradução de Celso Cunha. 2. ed. São Paulo: Martins Fontes, 2001. p. 43-44.

THORAVAL, Y. Diccionario de civilización musulmana. Barcelona: Larousse Planeta, 1996.

VARGENS, J. B. de M. Léxico português de origem árabe: subsídios para os estudos de filologia. Rio Bonito: Almádena, 2007.

VASCO DA GAMA, N. A variação do latim e a formação das línguas românicas. Qvinto Império, n. 5, p. 39-51, 1995.

VASCONCELOS, C. M. de. Fontes do léxico português: os elementos árabes. In: . Lições de filologia portuguesa. Lisboa: Revista de Portugal, 1956. p. 299-310.

Recebido em: 20 de julho de 2018. Aprovado em: 13 de agosto de 2018. 